\title{
DNA viruses associated with diseases of marine and anadromous fish
}

\author{
F. M. Hetrick \\ Department of Microbiology, University of Maryland; College Park, MD 20742, USA
}

\begin{abstract}
The association of DNA-containing viruses with diseases of marine and anadromous fish is reviewed. One section of the review describes those diseases with a proven viral etiology. Available information on the physical, chemical, and biological properties of the viruses is included. Another section deals with those diseases where a viral etiology is suspected but not established. The primary evidence associating viruses with many of these diseases is the observation of virus particles in electron micrographs of thin sections of tissue samples from diseased fish. Finally, the possible role of pollutants, and other stress factors, in predisposing fish to viral infection is discussed as are the problems associated with studying diseases of wild fish populations.
\end{abstract}

\section{INTRODUCTION}

The systematic study of viral diseases of fish began with the development of the first fish cell line by Wolf in 1960 . Today there are more than 25 confirmed or suspected viral diseases of fish [see reviews by McAllister (1979); Pilcher \& Fryer (1980); Wolf (1982)]. As in other types of intensive animal husbandry, viruses can cause explosive disease outbreaks in fish farming operations. When these epizootics occur, many tissue samples are available for laboratory workup. Also fish, generally homogenous with respect to size and age, are available as hosts for experimental transmission studies to test the pathogenicity of any viral isolates. Consequently, most of the better characterized viruses known today are pathogens for freshwater and anadromous fish species that are cultured on a large scale and hence economically important.

Viral diseases of marine fish are more difficult to study since they involve wild rather than captive populations. Current methodology favors the detection of those agents associated with large fish kills, such as the annual spring epizootics in the Atlantic menhaden (Stephens et al., 1980), or with chronic diseases like lymphocystis. It is certain that more diseases with a viral etiology occur in marine fish than are currently known. If the diseases are enzootic, rather than epizootic, they would probably go unnoticed. If they occur in commercially unimportant "trash" fish, they would not likely be investigated.

Nonetheless, the list of diseases associated with marine fish is growing (Sindermann, 1970). Hill, in this symposium, will review those viruses with an RNA genome that are of importance in the marine environment. This report describes the DNA-containing viruses that have been associated with diseases of marine and anadromous fish (Table 1). The first section describes those diseases with a known viral etiology while the 
Table 1. Diseases of marine and anadromous fish for which DNA viruses have a proven or suspected etiology

\begin{tabular}{|c|c|c|}
\hline Disease & Virus group & Species affected \\
\hline \multicolumn{3}{|l|}{ Viraletiologyconfirmed } \\
\hline Lymphocystis & Iridovirus & $\begin{array}{l}\text { Wide range of fresh and salt- } \\
\text { water fish ( }>80 \text { species) }\end{array}$ \\
\hline $\begin{array}{l}\text { Oncorhynchus masou virus } \\
\text { (OMV) }\end{array}$ & Herpesvirus & $\begin{array}{l}\text { Rainbow trout; masu, chum, } \\
\text { coho, and kokanee salmon }\end{array}$ \\
\hline Salmonid Herpesvirus disease & Herpesvirus & $\begin{array}{l}\text { Rainbow trout, kokanee or } \\
\text { sockeye salmon }\end{array}$ \\
\hline Erythrocytic necrosis & Iridovirus & $\begin{array}{l}\text { Variety of marine and anadro- } \\
\text { mous fish ( }>20 \text { species) }\end{array}$ \\
\hline \multicolumn{3}{|l|}{ Viraletiologysuspected } \\
\hline Carp gill necrosis & Iridovirus & Carp \\
\hline Epidermal hyperplasia & Adenovirus & Cod \\
\hline $\begin{array}{l}\text { Epithelioma papillosum } \\
\text { (carp pox) }\end{array}$ & Herpesvirus & Carp, chub, roach \\
\hline $\begin{array}{l}\text { Herpesvirus scopthalmi } \\
\text { (disease of turbot) }\end{array}$ & Herpesvirus & Turbot \\
\hline Pacific cod Herpesvirus & Herpesvirus & Pacific cod \\
\hline Ulcus syndrome & Iridovirus, Rhabdovirus & Atlantic cod \\
\hline Papillomatosis & $(125-150 \mathrm{~nm}$ particle $) ?$ & Atlantic salmon \\
\hline $\begin{array}{l}\text { Eel stomatopapilloma } \\
\text { (cauliflower disease) }\end{array}$ & $\begin{array}{l}\text { (52-56 nm particle)? } \\
\text { Orthomyxovirus }\end{array}$ & European eels \\
\hline
\end{tabular}

second section is devoted to a discussion of those diseases for which a viral etiology is suspected but not proven.

\section{DISEASES WITH A KNOWN VIRAL ETIOLOGY}

\section{Lymphocystis}

Lymphocystis is a chronic viral disease of marine, estuarine, and freshwater fish species which has a worldwide distribution. The disease was first reported in European flounder (Pleuronectes flesus); the first extensive study of lymphocystis was initiated by Weissenberg (1914) and continued for nearly 50 years (Weissenberg, 1965). The characteristic feature of the disease is the development of macroscopically visible whitish nodules, or groups of nodules, resembling warts on the skin and fins of affected fish. Although the disease is rarely fatal, fish with the disease are unsightly and, if caught, are discarded for aesthetic reasons.

At least 83 species of fish from 33 families in 7 orders are susceptible to the disease (McCosker et al., 1976; Lawler et al., 1977). Some of the species more recently shown to 
be infected include: winter flounder (Pseudopleuronectes americanus) reported by Murchelano \& Bridges (1976); Baltic flounder (Platichthys flesus) reported by Vitinsh \& Baranova (1976) and Russell (1974); Baltic herring (Clupea harengus var membras) reported by Aneer \& Ljungberg (1976); plaice (Pleuronectes platessa) reported by Russell (1974); Atlantic croaker (Micropogon undulatus) reported by Howse \& Christmas (1971); yellowfin sole (Limanda aspers) reported by Alpers et al. (1977); and striped bass (Morone saxatilis) by Krantz (1970).

Outbreaks of lymphocystis also occur in cultured fish. Stickney \& White (1974) reported infection of tank-cultured southern flounder (Paralichthys lethostigma and $P$. dentatus) and Paperna et al. (1982) described an outbreak in Sparus aurata cultured in the Gulf of Aqaba (Red Sea). Despite the broad host range of lymphocystis virus, the infection has never been reported in salmonid fish. Lymphocystis is a particular problem to aquarists as introduction of a single infected fish can result in all fish becoming infected because of the close confinement and the broad host range of the virus. Since the disease is slow in developing, the problem may not be evident soon enough to cull out the infected fish.

There appears to be some host influence on the virus. The disease can usually be transmitted among members of the same genus with ease, however, transmission between fish from different families is difficult and sometimes impossible. Variations in the seasonal prevalence of the disease have also been reported for different host species. Weissenberg (1945) reported peak occurrences among centrarchids in the winter while Nigrelli (1954) found the disease to be more common in freshwater species during the summer months, virtually disappearing in fall and winter.

The virus is introduced into the water via epithelial cells shed from infected fish or directly from disintegrating cells. The portal of entry for the virus into new hosts is probably through abrasions or injuries to the skin or fins since the warty growths usually appear on the areas most vulnerable to injury. The oral route of transmission may also occur if the host feeds on infected fish. In these cases, the lymphocystis cells occur in the gut, heart, and other internal organs. Additionally, the large lymphocystis cells may fall to the bottom where they may be ingested by bottom feeding fish. There is no evidence that the virus is transmitted by fish eggs, however, transportation of fish with the agent is a means of spreading the disease from one area to another.

There is no known therapy for lymphocystis. Control measures involve restriction of movement of infected fish, removal of dead fish from ponds or aquaria, and good sanitation practices in fish culture facilities. The disease can be diagnosed solely on the observation of the characteristic cell hypertrophy (Weissenberg, 1965). Lymphocystisinfected cells usually range from $100-250 \mu \mathrm{M}$ in diameter and may attain sizes up to $2 \mathrm{~mm}$ in flounder. The cells have a thick (8-10 $\mu \mathrm{M})$ hyaline membrane, large nuclei and nucleoli, and large basophilic inclusions at the periphery (Wolf, 1968).

Since cell-free filtrates of infected tissues produced the disease when inoculated into fish, a viral etiology for the disease was suspected (Weissenberg, 1951; Wolf, 1962). Electron microscopic evidence for virus involvement was reported by Walker (1962) who observed numerous virions, about $200 \mathrm{~nm}$ in diameter, in lymphocystis tumor cells of perch. Walker \& Wolf (1962) found similar particles in lymphocystis cells of bluegills (Lepomis macrochirus), often in crystalline arrays. The virus is most likely a member of the Iridovirus group. 
Isolation of lymphocystis disease virus (LDV) was first accomplished by Wolf et al. (1966) from infected bluegills in centrarchid fish cell lines. The virus can be serially propagated in bluegill fry (BF-2) cell cultures in which hypertrophy occurs within 2 to 3 weeks at $25^{\circ} \mathrm{C}$. Virus propagated in cell cultures produced lymphocystis disease when inoculated into normal bluegills and virus was subsequently isolated from the lesions (Wolf et al., 1966). The incubation period for lymphocystis is usually several weeks in experimentally infected bluegills. Progeny virus was first detected at 5 days and increased in titer up to 12 days following exposure. The development of lymphocystis lesions paralleled the virus multiplication and they continued to increase in size up to 30 days post-infection (Dunbar \& Wolf, 1966; Wolf \& Carlson, 1965).

Electron microscopy of infected BF-2 cells (Zwillenberg \& Wolf, 1968) showed polyhedral virions about $300 \mathrm{~nm}$ in diameter. Mature virions do not form in the main substance of the cytoplasmic inclusions but are located at its surface or scattered elsewhere. The inclusions are Feulgen positive and show yellow-green fluorescence after acridine orange staining (Walker, 1965) indicating the presence of DNA, presumably viral in nature.

Size estimates of LDV from different laboratories have varied from 130-150 nm (Walker \& Weissenberg, 1965) to $300 \mathrm{~nm}$ (Zwillenberg \& Wolf, 1968) in diameter depending on the materials and host species examined. Robin \& Berthiaume (1981) noted two distinct bands when LDV was purified by isopycnic centrifugation in metrizamide gradients. Examination of the bands by electron microscopy showed two sizes of particles: small, dense particles measuring $100-150 \mathrm{~nm}$ and lymphocystis virions that measured $300-350 \mathrm{~nm}$ in diameter. Since all of the infectivity was associated with the band containing the larger particles, one hypothesis presented was that the smaller particles were defective-interfering (DI) particles.

Madely et al. (1978) studied the fine structure of LDV from European flounder and plaice. The virus particles were 175 to $260 \mathrm{~nm}$ across and $200-300 \mathrm{~nm}$ between the vertices. The surface was devoid of clearly identifiable subunits. With storage at $4{ }^{\circ} \mathrm{C}$, the hexagonal outline was lost and knob-like subunits became visible. They were about $4.5 \mathrm{~nm}$ in diameter and appeared to be connected to the rest of the virion by a narrow stalk. Also seen in the broken-down virus was a spherical core with a tubular component, $13 \mathrm{~nm}$ in diameter, within it. This tubular material appeared to have a periodicity suggesting a helical conformation and may be a nucleocapsid. Analyses of the LDV genome has recently been reported (Darai et al., 1983). The genome is a doublestranded, linear DNA molecule with a molecular weight of $93 \pm 44 \times 10^{6}$. Denaturation and reannealing of the DNA resulted in the formation of circular molecules suggesting that terminal redundancy is present. Cytosine residues appear to be methylated. Restriction enzyme patterns and Southern blot hybridizations separated the isolates into two classes: one found in flounder and plaice, and the other in lesions of dabs.

Flügel et al. (1982) characterized the proteins from LDV isolates made from flounder, dab, and plaice. At least 33 structural proteins, with molecular weights ranging from 14 to $220 \mathrm{~K}$, were detected by PAGE analysis of purified virus preparations. Although the protein patterns were similar for the different isolates, slight but distinct differences were also noted.

Walker \& Hill (1980) reported a detailed study on the growth of LDV in a cell line (BF-W) derived from the fins and caudal tissue of bluegill sunfish. The virus was 
quantified by an enlarged-cell enumeration assay. Growth studies indicated that maximum virus titers of about $10^{6}$ cell-enlarging units $/ \mathrm{ml}$ were obtained after 14 to 21 days incubation at $25^{\circ} \mathrm{C}$. Virus replication also occurred at $20^{\circ} \mathrm{C}$ but the final titers attained were approximately one $\log$ lower. At $15^{\circ} \mathrm{C}$, there was only minimal viral multiplication and the virus not only failed to multiply at $30^{\circ} \mathrm{C}$ but seemed to be inactivated at this temperature.

Viral infectivity was not affected by ultrasonic treatment, freezing and thawing, or long-term storage in maintenance medium at 4 or $-70^{\circ} \mathrm{C}$. Infectivity was reduced by treatment with ether and viral replication was inhibited in the presence of a $1 \mathrm{mM}$ concentration of the pyrimidine analog 5-bromodeoxyuridine.

\section{Oncorhynchus masou virus}

Kimura et al. (1981a) reported the isolation of a virus in rainbow trout gonad (RTG-2) cell cultures from ovarian fluids of normal adult masu salmon (Oncorhynchus masou) during a survey of cultured salmon in Hokkaido, Japan. The agent was found to have characteristics of the Herpesvirus group and has been provisionally named $O$. masou virus (OMV). The virus was subsequently shown to be lethal for chum salmon (O. keta), coho salmon (O. kisutch), kokanee salmon (O. nerka) and rainbow trout (Salmo gairdneri). Infected fish were anorexic and exopthalmia and petechiation of the body surface occurred in some fish. Histopathological examination of liver sections showed multiple necrotic foci and syncytium development. Electron microscopy of infected liver tissue showed both empty capsids and nucleocapsids in the nuclei of infected cells.

Experimental infection of chum salmon showed that fry could be infected by immersion for $1 \mathrm{~h}$ in $10^{\circ} \mathrm{C}$ water containing $100 \mathrm{TCID}_{50} / \mathrm{ml}$ of OMV. The age of the fish employed was influential in the outcome of experimental infection. Eighty-day-old fry began to show mortalities at 11 to 12 days post-exposure and $60 \%$ of them succumbed within 65 days. OMV was isolated from most moribund fish examined with virus titers being approximately $10^{6} \mathrm{TCID}_{50} / \mathrm{g}$ of infected tissue. When 150 -day-old fry were used, deaths did not occur until 20 days post-infection and $35 \%$ of them died in the ensuing 120 days. There were no deaths among 240-day-old fish immersed in virus and additionally injected intraperitoneally with $200 \mathrm{TCID}_{50}$ of virus (Kimura et al., 1981a). In a subsequent study, Kimura et al. (1983) evaluated the susceptibility of fry of five salmonid species (chum salmon, masu salmon, kokanee salmon, coho salmon, and rainbow trout) to OMV. Using one-month-old fry, the relative sensitivity in terms of percent mortality was kokanee salmon $100 \%$, masu salmon $87 \%$, chum salmon $83 \%$, coho salmon $39 \%$, and rainbow trout $29 \%$, respectively.

The virus replicated in all seven salmonid cell lines in which it was tested (Kimura et al, 1981c), but it did not grow in four non-salmonid cell lines-brown bullhead (BB), fathead minnow (FHM), epithelioma of carp (EPC), and sea bream kidney (SBK). The virus replicated optimally at $15^{\circ} \mathrm{C}$ but not at all at $25^{\circ} \mathrm{C}$ or higher. Distinctive $\mathrm{CPE}$ and syncytium formation occurred within $5-7$ days at $15^{\circ} \mathrm{C}$ with maximum titers attained being approximately $10^{6} \mathrm{TCID}_{50} / \mathrm{ml}$. Electron microscopy of infected cells revealed hexagonal capsids in the nucleus approximately $115 \mathrm{~nm}$ in diameter. Enveloped virions, 200-250 nm in diameter, were seen at the cell surface and inside cytoplasmic structures.

The virus was found to be heat $\left(50^{\circ} \mathrm{C}\right.$ for $\left.30 \mathrm{~min}\right)$ and acid ( $\mathrm{pH} \mathrm{3}$ ) labile. It was 
inactivated by treatment with ether, and was inhibited by $50 \mu \mathrm{g} / \mathrm{ml}$ of the pyrimidine analogue, 5-iododeoxyuridine. Replication was also inhibited by phosphonoacetic acid and acycloguanosine, two newly developed anti-herpesvirus drugs. The virus was found to be serologically distinct from Herpesvirus salmonis. Taken together, the above virus characteristics clearly indicate that $\mathrm{OMV}$ is a new fish herpesvirus.

In addition to producing acute disease in juvenile salmon, OMV has also been reported to induce epithelial tumors among survivors of the acute infection (Kimura et al., 1981b, c). Fifty-two 5-month-old chum salmon that survived experimental infection were held for additional observation. After 4 months, neoplasms appeared around the mouth and subsequently on the eyeball and caudal fin. Tumors were noted in more than $60 \%$ of the fish by 8 months post-infection. Some fish developed multiple tumors and one had a tumor in the kidney. Viral particles were not seen in the tumor cells, however, OMV isolations were made from one tumor tissue sample that appeared necrotic on day 275 and from primary cell cultures prepared from the tumor tissue of another fish sampled on day 296 postinfection.

A repeat experiment in chum salmon gave the same general results, i.e. tumors developed in survivors approximately 4 months post-infection. Similar results were obtained in experiments with coho salmon and rainbow trout. Thus, OMV shows pathogenicity for salmonids not only in causing hepatic necrosis and death, but also in inducing tumors among many survivors of the acute disease. These elegant studies by Kimura and his coworkers are the first description of a bonafide oncogenic virus for fish.

\section{Salmonid herpesvirus disease}

An agent, with the general characteristics of a herpesvirus, was isolated from broodstock rainbow trout suffering postspawning losses at the National Fish Laboratory in Winthrop, Washington, USA (Wolf, 1976). Infected rainbow trout became lethargic before death and exopthalmia was common. Many fish darkened in color, showed abdominal distension, and some had thick fecal pseudocasts. Histological examination showed major pathological changes in the gills, heart, kidneys, and liver. There was widespread fatty infiltration and edema in the liver. In some cases, Cowdry Type A intranuclear inclusions were seen in liver cells and syncytia were observed in pancreatic tissue (Wolf, 1979).

Characterization of the virus, named Herpesvirus salmonis, was first reported by Wolf et al. (1978). Infection of RTG-2 cells resulted in the formation of syncytia and Type A intranuclear inclusions. Studies on the growth kinetics of the virus revealed an unusual characteristic of the virus, namely, an optimal temperature for replication between $5-10^{\circ} \mathrm{C}$. Syncytia formed at $0^{\circ} \mathrm{C}$ but the infection was otherwise abortive. Viral replication was depressed at $15^{\circ} \mathrm{C}$ and completely inhibited at higher temperatures. The virus was acid, heat, and chloroform labile but stable to freezing and thawing. Viral DNA had a buoyant density of $1.709 \mathrm{~g} / \mathrm{cm}^{3}$ and a guanine-cytosine value of $50 \%$. Electron microscopic examination of infected cells showed hexagonal nucleocapsids approximately $90 \mathrm{~nm}$ in diameter which were first seen in nuclei at $36 \mathrm{~h}$. Enveloped virions measured $150 \mathrm{~nm}$ in diameter and occurred both cytoplasmically and extracellularly. Infectivity studies showed that cell-associated virus titered approximately one log higher than that obtained with fluids from infected cells. 
The disease can be reproduced in rainbow trout fry and small fingerlings by inoculation of cell culture grown virus (Wolf et al., 1975a, b, 1978). In several trials at temperatures from 6 to $12^{\circ} \mathrm{C}, 3$ to 6 weeks elapsed before the first death with additional mortalities occurring during the next 3 to 4 week period. Virus was readily isolated from the tissues of moribund fish. As with the natural disease, the major pathological changes in experimentally-infected fish were found in the gills (epithelial edema), heart (edema and necrosis), kidney (edema), and liver (fatty vacuolation and edema). The rectal portion of the intestine showed mucosal necrosis and sloughing of cells which contributed to the formation of fecal casts (Wolf, 1979).

In a more recent study, Wolf \& Smith (1981) studied the pathological changes in parenterally-infected rainbow trout. The virus produced a generalized infection within 2 to 3 weeks. Highest virus levels $\left(10^{6} \mathrm{TCID}_{50} / \mathrm{g}\right.$ of tissue) were found in the kidney with lesser amounts being present in the stomach, liver, and intestine. Visceral organs and the heart showed major pathological changes, and syncytia in the pancreas were considered to be pathognomonic.

Rainbow trout fry and fingerlings and kokanee or sockeye salmon are the only known susceptible species. Since $H$. salmonis was originally isolated from ovarian fluid samples, vertical transmission of the agent may occur. Fish to fish transmission is assumed during epizootics. However, in a controlled study (Wolf \& Smith, 1981), the disease failed to spread to normal rainbow trout cohabitated with infected fish for 9 days.

A very similar agent has been isolated in Japan. Beginning in 1970, epizootics among fry of another salmonid species (Oncorhynchus merka) were noted annually in Japanese fish farms from June to September (Sano, 1976). In 1972, a virus was isolated which formed syncytia in RTG-2 cells and which was shown to have typical herpesvirus morphology. The agent was named NeVTA virus for nerka virus in Towanda Lake, Akita and Amori prefectures.

Sano (1976) believes that NeVTA virus is different from $H$. salmonis even though it has the same low temperature requirement for replication. He reported an $80 \%$ mortality rate among naturally infected $O$. nerka. In contrast, the North American isolate killed rainbow trout but no young $O$. nerka. Studies utilizing more modern techniques, such as DNA-DNA hybridizations and antigenic characterizations with monoclonal antibodies, are needed to clarify the relationships between $H$. salmonis and NeVTA and with OMV as well.

\section{Viral erythrocytis necrosis}

Infections of erythrocytes characterized by cytoplasmic inclusion bodies and nuclear alterations have been reported in a wide range of poikilothermic vertebrates including amphibians (Bernard et al., 1968) and reptiles (Stehbens \& Johnston, 1966). However, the disease has been most studied in marine and anadromous fish and this discussion will be confined to those infections.

Piscine erythrocytic necrosis (PEN) was the name given by Laird \& Bullock (1969) to describe a pathological condition in the erythrocytes of three fish species, cod (Gadus morhua), seasnail (Liparia atlanticus) and sculpin (Mycocephalus scorpius) collected in coastal waters of eastern Canada and the northeastern United States. The infection is easily identified by the presence in affected erythrocytes of characteristic acidophilic, 
intracytoplasmic inclusion bodies (Appy et al., 1976; Walker \& Sherburne, 1977). Nuclear degeneration is also frequently observed, especially in Atlantic cod (Walker \& Sherburne, 1977). Since there is redundancy in referring to PEN in specific fish, the infection is now more appropriately known as VEN, for viral erythrocytic necrosis (Evelyn \& Traxler, 1978).

The host range of VEN is broad and includes over 20 species of marine and anadromous fish. There is only limited distribution data on VEN. To date, the major species involved are cod and herring off the eastern coast of North America, salmon and herring from the Pacific coast of North America, dogfish from the Bay of Naples, and cod and blenny in coastal and offshore waters of the United Kingdom (Smail \& Egglestone, 1980). The prevalence of the infection ranges between 1 and $90 \%$ depending on the species and geographic location sampled. The intensity of infection in any individual may vary from only a rare inclusion body to virtually $100 \%$ of the erythrocytes examined (Nicholson \& Reno, 1981).

In Pacific salmon, the disease has been diagnosed over a wide range of temperatures $\left(6.5-19^{\circ} \mathrm{C}\right)$ but appears to be most severe during the summer (Evelyn \& Traxler, 1978). With the exception of anemia in naturally and experimentally infected salmonids, no clinical signs of disease are apparent (Evelyn \& Traxler, 1978). In this regard, Reno \& Nicholson (1980) have demonstrated that erythrocytes from affected Atlantic cod were significantly more susceptible to lysis when maintained in vitro than were erythrocytes from uninfected cod.

As yet, erythrocytic necrosis virus (ENV) has not been associated with massive mortalities of fish. Evelyn \& Traxler (1978) reported mortalities up to $0.3 \%$ per day in chum salmon that were attributable to VEN, however, the natural outbreaks were usually complicated by the presence of vibriosis and bacterial kidney disease. Rohovec \& Amandi (1981) reported cytoplasmic inclusions in the erythrocytes of spawning coho and chinook salmon and steelhead trout in Oregon hatcheries. They also reported inclusions in juvenile coho salmon which were suffering mortalities, the first such observation of VEN in fish reared solely in fresh water. Since the deaths could not be attributed to other viral or bacterial pathogens, toxic agents, or environmental factors, this may be the first instance reported in which mortality was directly attributable to VEN. Sherburne (1977) reported a higher incidence of VEN in pre-spawning than in the post-spawning alewife (Alosa pseudoharengus) and MacMillan \& Mulcahy (1979) observed a higher prevalence in young Pacific herring (Clupea harengus pallasi) than in older fish. Both of these observations could be explained by a loss of infected fish from the population.

Evidence is accumulating which indicates that while VEN itself may not directly cause large fish losses, it may weaken and predispose infected fish to secondary problems. MacMillan et al. (1980) described some secondary consequences of erythrocytic necrosis virus (ENV) infection of chum salmon. Under experimental conditions, they reported that fish infected with VEN averaged 2.6 times greater mortality than control fish when challenged with Vibrio anguillarum and they showed a shorter time-to-death as well after bacterial exposure. Re-isolation of $V$. anguillarum was possible in $98 \%$ of the fish with VEN but in only $5 \%$ of the control fish. They also reported that fish with VEN had a significantly decreased tolerance to oxygen depletion, and a decreased ability to regulate serum sodium and potassium in saltwater. That environmental stress 
can have a significant impact on the outcome of host-pathogen confrontations has been reviewed by Snieszko (1974) and Wedemeyer (1976). Thus, VEN infection of fish may be important in limiting their survival in the wild by rendering them more susceptible to mortalities from other factors.

The first evidence of a possible viral etiology for VEN was reported by Walker (1971). Electron microscopic observation of erythrocytes from affected cod revealed the presence of large cytoplasmic particles with a hexagonal profile. The particles were similar in appearance to virions of the Iridovirus group. Subsequent electron microscopic studies have shown that, at the ultrastructural level, virions associated with VEN in different species show significant differences. Walker \& Sherburne (1977) reported that the virus associated with VEN in Atlantic cod has an average diameter of $330 \mathrm{~nm}$. The electron dense nucleoid was spheroidal and approximately $230 \mathrm{~nm}$ in diameter. All the virions were cytoplasmic and adjacent to the viroplasm as an inclusion complex. Reno et al. (1978) studied the ultrastructure of virus in erythrocytes from VEN-infected Atlantic herring. The virions were hexagonal or pentagonal and $145 \mathrm{~nm}$ in diameter when measured edge to edge. Structural details reported were an outer electron dense layer $8 \mathrm{~nm}$ wide, a less electron dense layer $16 \mathrm{~nm}$ wide and a densely staining core approximately $100 \mathrm{~nm}$ in diameter which contained a $40 \mathrm{~nm}$ central electron translucent area. The ENV of herring then more closely resembles that described in salmonids (Evelyn \& Traxler, 1978) and is distinct from that in cod or blenny (Reno \& Nicholson, 1981).

In summary of the electron microscopic studies, the viruses seen in the cytoplasm of affected cells appear to fall into three size classes and are characteristic for the host species involved: 140-190 $\mathrm{nm}$ in Atlantic herring (Reno et al., 1978) and Oncorhynchus spp. (Evelyn \& Traxler, 1978); 200-250 nm in blenny (Johnston \& Davies, 1973); and 300-350 nm in Atlantic cod (Appy et al, 1976; Walker \& Sherburne, 1977).

There may be marked alterations in the ultrastructural appearance of erythrocytes from affected fish. In VEN-infected herring, the surface of affected erythrocytes was irregularly lobated and often lost its elliptical shape (Reno et al., 1978). Another morphologic change noted was margination of nuclear chromatin, evident as an accumulation of electron-dense material at the periphery of the nucleus. Reno et al. (1978) report two types of cytoplasmic inclusions when affected erythrocytes were reviewed by electron microscopy. Type 1 were round, granular, electron dense, and up to $1.5 \mu \mathrm{M}$ in diameter. Virus particles were associated with this type of inclusion either at the periphery or occasionally in the interior. Type II inclusions were membrane-bound structures which had the same appearance as the surrounding cytoplasm. Virions were not seen in these inclusions.

Evelyn \& Traxler (1978) reported successful transmission of the disease to chum and pink salmon following intraperitoneal (i. p.) inoculation of filtered extracts prepared from infected chum salmon kidney tissue. In exposed pink salmon, VEN was evident at 3 weeks post-inoculation in 9 of 10 fish exposed to the agent. In chum salmon, the proportion of VEN-infected fish increased from $50 \%$ at 12 days post-inoculation to $100 \%$ by Day 48 . Seven of the fish escaped bacterial infection and survived for 7 months at which time four had become VEN negative indicating that fish may recover from the disease and not be life-long carriers. Fish inoculated with heated $\left(60^{\circ} \mathrm{C}\right.$ for $\left.15^{\prime}\right)$ extract did not develop the infection indicating that VEN is relatively heat labile. Transmission of VEN in adult cod by intraperitoneal injection of washed, whole erythrocytes has been 
reported by Nicholson \& Reno (1981). After 3 to 4 weeks, the characteristic inclusions appeared reaching an intensity of $45-50 \%$ infected erythrocytes after several months and declining thereafter.

Since all attempts to culture VEN have thus far been unsuccessful, Reno \& Nicholson (1980) developed a method for maintaining erythrocytes in vitro from infected Atlantic cod for use in studying VEN infection in erythrocytes. The optimal conditions for maintenance employed static cultures at $4^{\circ} \mathrm{C}$ in a cell culture medium (MEM) with 10-15\% fetal calf serum. Under these conditions, erythrocytes could be held for at least two weeks with less than $50 \%$ lysis. To study the effect of VEN on macromolecular syntheses, the incorporation of radio-labelled precursors by erythrocytes from infected and uninfected cod was followed. In these experiments the percent of VEN-infected erythrocytes was in the range of $10-20 \%$. When ${ }^{3} \mathrm{H}$-uridine was employed, there was no difference in uptake by the two cell populations, however, when tritiated amino acids were used, the level of incorporation by infected erythrocytes was double that of normal cells. The most pronounced effect noted was on DNA synthesis. There was no appreciable incorporation of ${ }^{3} \mathrm{H}$-thymidine over the course of the experiment (13 days) by cells from VEN-negative fish. In contrast, there was a continuing uptake of label by infected cells until the sixth day, at which time the level of thymidine incorporation was 10 times that seen in uninfected cells. This is the first evidence indicating that the virus may be replicating in infected erythrocytes.

Despite repeated attempts by many investigators, VEN virus has not been successfully grown in a cell culture system. Nevertheless, the finding of Iridovirus-like particles in many species and the successful transmission of the disease makes it quite likely that VEN has a viral etiology. Certainly the evidence is as compelling as that which linked viruses to hepatitis in humans before laboratory hosts became available.

\section{DISEASES WITH SUSPECTED VIRAL ETIOLOGY}

\section{Carp gill necrosis}

Little information is available on this disease and what is described here was taken from a review by Wolf (1982). Popkova \& Schelkunov (1978) reported the isolation of a large cytoplasmic Iridovirus-like agent from carp on farms in Russia suffering from gill necrosis. The agent was isolated in FHM cells using materials from the gills and kidney of infected fish as inocula. Cytopathic effects were seen with most of the samples but, except for one isolate, passage of the materials resulted in a loss of cytopathology. Electron microscopy showed icosahedral particles approximately $200 \mathrm{~nm}$ in diameter. Experimental transmission of the infection was apparently successful. No other information is available.

\section{Epidermal hyperplasia of cod}

During a study of the ulcus-syndrome in cod (Gadus morhua), Jensen \& Larsen (1979) noted a few cases of an unknown but characteristic skin disease in cod in Danish waters. The lesions appeared as transparent round spots and they occurred over the entire body surface. Histopathological examination showed the epidermis in the lesion 
to be about four times the normal thickness and it contained few or no mucosal glands. When the affected tissue was examined by electron microscopy, virus-like particles were seen in the nuclei of some epithelial cells. The particles showed both hexagonal and pentagonal outlines, the characteristic shape of icosahedral viruses in thin sections. The particles were approximately $77 \mathrm{~nm}$ in diameter and had $20-25 \mathrm{~nm}$ long thin fibers projecting from the corners (Jensen $\&$ Bloch, 1980). Taken together these characteristics, i.e. size, morphology, presence of fibers, and nuclear location, strongly indicate that the agent is a member of the Adenovirus group. This is the first report of Adenovirus-like particles in fish. The agent has not been grown in cell cultures nor has the disease been experimentally transmitted among fish.

\section{Carp pox}

Carp pox (Epithelioma papillosum) has long been known as a disease of cultured carp. Common carp (Cyprinus carpio) and several other cyprinids in Europe, Asia, and the Middle East develop the disease. The epidermal hyperplasia is characterized by raised, white verrucose plaques that occur on many parts of the body particularly the gills, skin, eyes, and fins. The tumor is benign as there is no evidence of visceral metastasis (Sonstegard \& Sonstegard, 1978). Since the disease is innocuous, it has received scant attention.

A viral etiology is suspected but not proven. Herpesvirus-type particles have been observed in infected tissues (Schubert, 1966). The virions become enveloped as they pass from the nucleus to the cytoplasm, a general feature associated with herpesvirus replication. Cowdry Type A nuclear inclusions have been reported but syncytia have not been seen in sections of infected tissue.

The infection is readily transmitted to normal carp either by rubbing tumor tissue against the abraded epithelium of normal carp or by holding normal carp in the same tank as infected fish. Tumors develop in about 60 days at $10^{\circ} \mathrm{C}$. Within the nucleus of tumor cells, large aggregates of non-enveloped virions are seen (Sonstegard \& Sonstegard, 1978). The virus has not yet been isolated in cell culture.

\section{Herpesvirus scophthalmi infection of turbot}

The first outbreak of this disease was noted in turbot (Scophthalmus maximus) which were moved from a hatchery in Scotland to a warm-water ongrowing site which used heated effluent from a power station. Affected fish were lethargic and did not feed. Mortalities in the affected stock reached $30 \%$ although a proportion of these losses were attributable to other causes (Richards \& Buchanan, 1978). Most deaths occurred within 5 days of the original transportation and increased during periods of temperature change and elevated chlorine levels in the power plant effluents.

There were no lesions in any organs except the gills and skin where giant cells, some as large as $170 \mu \mathrm{M}$ in diameter, were distributed among epidermal cells. No bacteria were isolated from internal organs but electron microscopy revealed herpesvirus-type particles within both the nucleus and cytoplasm of the giant cells (Buchanan et al., 1978). The particles in the nucleus were hexagonal in shape and approximately $100 \mathrm{~nm}$ in diameter. Those in the cytoplasm had an outer envelope which was covered 
with peplomers approximately $18 \mathrm{~nm}$ long and measured 200-220 $\mathrm{nm}$ in diameter. The nuclei within the syncytia fused to form a single giant oval nucleus with a maximum width of $60 \mu \mathrm{M}$ and a length of $100 \mu \mathrm{M}$ (Buchanan \& Madely, 1978). Paracrystalline arrays of the $100 \mathrm{~nm}$ particles were seen in these large nuclei. A subunit structure was clearly visible in negatively-stained preparations. The capsomeres appeared "hollow" and were approximately $9 \mathrm{~nm}$ in diameter. The agent has yet to be isolated in cell culture.

Release of the virus from infected fish probably occurs during giant cell destruction and the sloughing of epidermal cells. Reexamination of histopathological sections from wild turbot caught in previous years showed the presence of similar giant cells suggesting that the virus is endemic in wild fish (Buchanan et al., 1978).

\section{Herpes virus of Pacific cod}

McArn et al. (1978) and McCain et al. (1979) reported the occurrence of two main types of skin lesions on the Pacific cod (Gadus macrocephalus) collected in the Bering Sea. One of the lesions was ulcerative, the other was a raised, ring-shaped lesion. In the epidermal areas of the ring-shaped lesion were large cyst-like bodies, or giant cells, contained a basophilic center surrounded by an eosinophilic margin. Electron-microscopic examination of the giant cells showed the presence of herpesvirus-like particles. The particles seen in the nuclei were $80-100 \mathrm{~nm}$ in diameter whereas larger particles, 120-170 $\mathrm{nm}$ in diameter, were observed in the cytoplasm (McArn et al, 1978). The agent has not been isolated and its role in the etiology of the disease is unknown.

\section{Cod ulcus syndrome}

The cod ulcus disease is an ulcerating condition in the skin of Atlantic cod (Gadus morhua) taken from the coastal waters of Denmark. Jensen \& Larsen (1979) described various stages of progression of the disease from examining lesions on wild fish. The first stage is the appearance of multiple dermal papules, some of which may be hemorrhagic. These may develop into grey to yellow crater-like perforations of the skin which in turn may lead to varying degrees of ulceration with the lesions being $2-8 \mathrm{~cm}$ in diameter. The disease can result in significant mortalities.

Two different viruses have been isolated from affected cod (Jensen et al., 1979). One has a rhabdovirus-like morphology being a rod-shaped particle $55 \mathrm{~nm}$ wide and $175 \mathrm{~nm}$ in length. Blind passage of cod materials in a pike sarcoma line at $15^{\circ} \mathrm{C}$ resulted in the isolation of the agent. It caused sloughing of the cells in 3-4 days and reached a titer of approximately $10^{5} \mathrm{TCID}_{50} / \mathrm{ml}$. The other agent was an icosahedral particle, with an Iridovirus-like morphology. The virus had an overall diameter of $150 \mathrm{~nm}$ and a central nucleoid about $100 \mathrm{~nm}$ in diameter. This virus was isolated by blind passage in EPC cells. When adapted, it produced cytopathic effects within $20 \mathrm{~h}$ post-inoculation and attained titers of $10^{5} \mathrm{TCID}_{50} / \mathrm{ml}$.

Some experimental results suggest that the disease is infectious. Transmission was noted when homogenates of the early papular tissues were injected intraperitoneally or applied to scarified skin. Also, when healthy cod were placed in a tank with cod bearing the early dermal papules, they all developed the disease within 11 days. When 36 cod 
were inoculated intracardially with the Iridovirus, 8 developed the early papular stage of the disease as did one control fish (Jensen \& Larsen, quoted by Wolf, 1982). Development of the disease in the control fish illustrate the difficulty in transmission studies where wild fish need to be employed since nothing is known of their immune status or general health history.

\section{Atlantic salmon papillomatosis}

Although recognized for years in wild salmon (Salmo salar), epidermal hyperplasia or papillomatosis was first reported in hatchery fish in Sweden (Wiren, 1971). More recently, the disease was described in marine cultured rainbow trout (Roberts \& Bullock, 1979). The growth begins as a whitish, raised plaque which gradually increases in size and develops a verrucose surface. Lesions appear in late summer and the incidence may approach $50 \%$. Mature lesions may undergo necrosis but they are usually resolved by a graft-rejection-like slough (Carlisle \& Roberts, 1977). Mortality is low and when it does occur it is usually associated with secondary mycotic infections.

Virus-like particles are regularly seen in infected tissues and eosinophilic inclusion bodies are common. The virus particles are $125-150 \mathrm{~nm}$ in diameter. An outer coat is separated from an electron-dense nucleoid, 70-95 nm diameter, by an electron-lucent area (Carlisle, 1977). Four passages of papilloma material in Atlantic salmon cell cultures failed to yield a cytopathic agent. Similarly, attempts to experimentally transmit the tumor have been unsuccessful.

Bylund et al. (1980) described an interesting outbreak in cultured Atlantic salmon in Finland. The salmon were kept in 22 tanks and at weekly intervals were subjected to prophalytic baths of $2-3 \% \mathrm{NaCl}$ or formalin $(1-4000)$ alternatively. Two tanks were excluded from the prophylaxis for the first several weeks. During the rearing season, papillomatosis occurred in only these two tanks with $80-90 \%$ of the fish being affected. Since the fish in all the tanks were handled similarly in all respects, the early prophylactic treatment seems to have prevented the infection.

The tendency of the disease to occur in epizootics suggests a microbial etiology. Whatever the agent, it is widespread in nature as the disease has been noted in several countries, in fresh and salt water, and in hatchery and wild fish.

\section{Stomatopapilloma of eels (cauliflower disease)}

This disease of the European eel (Anguilla anguilla) is characterized by papillomatous growths which can occur anywhere on the eel's body but most frequently form about the head and mouth. The term cauliflower disease is descriptive of the growth which results from the infolding of the surface of the papilloma. The growth can result in complete obstruction of the mouth which leads to starvation of the affected eels. The disease occurs mainly in European coastal waters. The prevalence of the disease appears to be increasing (Deys, 1976) with the incidence approaching $40 \%$ in some areas.

At least three viruses have been isolated from eels with the disease. A virus with polyhedral symmetry and a diameter of $52-56 \mathrm{~nm}$ has been isolated in RTG-2 and FHM cells from the blood of infected eels. It is believed to replicate in the nucleus and, therefore, be a DNA virus (Pfitzner, 1969; Pfitzner \& Schubert, 1969; Schmid, 1969; 
Koops et al., 1970). However, the cell culture grown virus has not produced the disease when inoculated into eels.

Wolf \& Quimby (1970) isolated a similar virus from tumor homogenates. This virus, termed EV-1, produced large syncytia and pyknotic foci in RTG-2 cells. The virus has not been further characterized. Nagabayashi \& Wolf (1979) reported the isolation of a second virus (EV-2) in FHM cells from eels with stomatopapilloma. From its biological, physical, and chemical properties, they concluded that it was most probably an orthomyxovirus. When injected into elvers, about half of them died within 2 months but virus could be recovered from only $25 \%$.

It should also be pointed out that Peters \& Peters (1970) have reported the induction of similar proliferations in eels following their treatment with certain chemicals. Whether any of the three viruses, either alone or synergistically with a chemical agent, are involved in the etiology of this disease remains to be determined.

\section{POLLUTION AND DISEASE}

While this topic is covered in depth elsewhere in this symposium, a few comments are appropriate here. In recent years, chemical pollutants have been increasingly implicated in fish disease outbreaks [see reviews by Snieszko (1974) and Sindermann (1979)]. Much of the evidence is circumstantial such as increased frequencies of diseases in polluted waters or diseases occurring in fish being used for toxicity studies. However, in the last few years, controlled laboratory studies have demonstrated altered susceptibility to pathogens or impaired immunological responses in fish exposed to pollutants, mostly heavy metals.

Zinc, copper, and methylmercury have been reported to reduce the antibody response of two exotic fish species, zebrafish (Sarot \& Perlmutter, 1976) and blue gourami (Roales \& Perlmutter, 1977) to bacterial and viral antigens. Hetrick et al. (1979) found that young rainbow trout were more susceptible to infectious hematopoietic necrosis virus following exposure to sub-lethal copper levels. Increased susceptibilities of steelhead trout to Yersinia ruckeri (Knittel, 1981) and chinook salmon and rainbow trout to Vibrio anguillarum (Baker et al., 1983) have also been noted following sub-lethal copper exposure. In coho salmon, Sugatt (1980) reported increased susceptibility and reduced agglutinin titers to $V$. anguillarum following chromium exposure.

To date, controlled studies of pathogen-pollutant interaction, such as those described above, have not been reported with marine fish. Nevertheless, natural chemical "stresses" are undoubtedly being imposed on wild fish populations. These stresses, which can predispose the fish to infection with opportunistic pathogens, will only increase unless "the solution to pollution is dilution" practice is abandoned by coastal communities. One hallmark of the Herpesviruses is that they frequently establish latent infections in their hosts, being activated only when some stress is applied to an individual. Half of the diseases described in this review have a known or putative herpesvirus associated with their etiology. This might not be simply fortuitous but could indicate that stress factors caused a significant increase in the incidence of these diseases so that they became apparent.

While many fish kills have been directly traceable to the introduction of toxic pollutants, the effects of low levels of pollutants on fish species are probably more 
important than the occasional "large spill" since the effects are less likely to be obvious and the source more difficult to detect in time to save the environment. Documentation of these subtle effects has been difficult to achieve. Attempts to obtain indirect evidence of stress effects have included measurement of specific enzyme activities, steroid levels, and ability to suppress the immune response.

One aspect of the immune system that has not been exploited in attempts to find a suitable assay is the phagocytic system. For a number of reasons, this system seems to be a point of vulnerability which warrants evaluation as an indicator of adverse effects of pollutants on fish. Phagocytosis has been clearly established as a major defense mechanism in fish. In addition to the ingestion and killing of microorganisms, the phagocytic system is also important in the stimulation of antigen-specific immune responses (Rijkers, 1982) and it is enhanced by activation of the complement system. Since several defense mechanisms focus in the phagocytic system, it follows that factors which interfere with normal phagocytosis in fish would be accompanied by adverse effects including lowered resistance to infection and increased mortality, particularly from opportunistic pathogens.

Measurement of phagocytosis has been greatly simplified since Allen et al. (1972) reported that cells phagocytizing bacteria exhibited a chemiluminescence (CL) response due to the generation of oxygen radicals during a respiratory burst. We have developed a $\mathrm{CL}$ assay for studying the effect of various factors and conditions on the phagocytic activity of cells from the pronephros of striped bass (Stave et al., 1983) using modifications of a method reported by Scott \& Klesius (1981). Evidence to date indicates that certain heavy metals and pesticides depress the ability of striped bass phagocytes to engulf bacterial pathogens (Stave et al., unpubl.). We plan to expand these studies to other finfish and shellfish species to determine if the CL assay has predictive value in identifying those environmental pollutants that predispose fish to infection. The relative simplicity, inexpensive nature and rapidity with which results are obtained are attractive features of the CL assay.

The production of farmed fish is increasing on a global scale in an attempt to produce high quality protein for burgeoning populations, particularly in developing nations. The Food and Agricultural Organization (FAO) predicts that there will be a 5fold increase over 1975 production levels by the end of the century (Hill, 1981). While most of the world's production of farmed fish is currently reared in earth ponds, recent improvements in hatchery methods, cage construction, knowledge of migratory habits, and demonstration of fiscal viability have promoted interest in "sea-ranching" as an alternative approach.

Intensive marine fish farming has been particularly successful with salmon, red seabream, and yellowtail. Mass culture of other species will undoubtedly be attempted in the near future. Control of disease problems will be paramount in determining the success of these ventures. In addition to describing specific etiologic agents for diseases of cultured marine fish, research workers will also need to address the equally important problem of elucidating those environmental factors which predispose fish to infection. 


\section{LITERATURE CITED}

Allen, R. C., Sternholm, R. L. \& Steele, R. H., 1972. Evidence for generation of an electronic excitation state in human polymorphonuclear leukocytes and its participation in bactericidal activity, - Biochem. biophys. Res, Commun. 47,679-691.

Alpers, C. E., McCain, B. B., Meyers, M. S. \& Wellings, S. B., 1977. Lymphocystis disease in yellowfin sole (Limanda aspers) in the Bering Sea. - J. Fish. Res. Bd Can. 34, 611-618.

Aneer, G. \& Ljungberg, O., 1976. Lymphocystis disease in Baltic herring (Clupea harengus var membras). - J. Fish Biol. 8, 345-350.

Appy, R. G., Burt, M. D. B. \& Morris, T. J., 1976. Viral nature of piscine erythrocytic necrosis (PEN) in the blood of Atlantic cod (Gadus morhua). - J. Fish. Res. Bd Can. 33, 1380-1385.

Baker, R. J., Knittel, M. D. \& Fryer, J. L, 1983. Susceptibility of chinook salmon (Oncorhynchus tshawytoscha) and rainbow trout (Salmo gairdneri) to infection with Vibrio anguillarum following sublethal copper exposure. - J. Fish Dis. 6, 267-276.

Bernard, G. W., Cooper, E. L. \& Mandell, M. L., 1968. Lamellar membrane encircled viruses in the erythrocytes of Rana pipiens. - J. Ultrastruct. Res. 26, 8-16.

Buchanan, J. S. \& Madeley, C. R., 1978. Studies on Herpesvirus scophthalmi infection of turbot Scophthalmus maximus - Ultrastructural observations. - J. Fish Dis. 1, 283-295.

Buchanan, J. C., Richards, R. H., Madeley, C. R. \& Somerville, C. S., 1978. A Herpes-type virus from the turbot, Scophthalmus maximus, - Vet. Rec, 102, 527-528.

Bylund, G., Valtonen, E. T. \& Niemelä, E., 1980. Observations on epidermal papillomata in wild cultured Atlantic salmon (Salmo salar) in Finland. - J. Fish Dis. 3, 525-528.

Carlisle, J. C., 1977. An epidermal papilloma of the Atlantic salmon. II. Ultrastructure and etiology. - J. Wildl. Dis, 13, 235-239.

Carlisle, J. C. \& Roberts, R. J., 1977. An epidermal papilloma of the Atlantic salmon (Salmo salar). I. Epizootiology, pathology, and immunology. - J. Wildl. Dis, 13, 230-234.

Darai, G., Anders, K., Koch, H., Delius, H., Gelderblom, H., Samalecos, C. \& Flügel, R., 1983. Analysis of the genome of fish lymphocystis disease virus isolated directly from epidermal tumours of Pleuronectes. - Virology 126, 466-479.

Deys, B. F., 1976. Atlantic eels and cauliflower disease (Orocutaneous papillomatosis). - Prog. exp. Tumor Res. 20, 94-100.

Dunbar, C. E. \& Wolf, K., 1966. The cytological course of experimental lymphocystis in the bluegill. - J. infect. Dis. 116, 466-475.

Evelyn, T. P. T. \& Traxler, G. S., 1978. Viral erythrocytic necrosis: Natural occurrence in Pacific salmon and experimental transmission. - J. Fish. Res. Bd Can. 35, 903-907.

Flügel, R. M., Darai, G. \& Gelderblom, H., 1982. Viral proteins and adenosine triphosphate phosphohydrolase activity of fish lymphocystis disease virus. - Virology 122, 48-55.

Hetrick, F. M., Knittel, M. D. \& Fryer, J. L., 1979. Increased susceptibility of rainbow trout to infectious hematopoietic necrosis virus after exposure to copper. - Appl. environ. Microbiol. 37. $198-201$.

Hill, B. J., 1981. Virus diseases of fish. In: Virus diseases of food animals. Ed. by E. P. J. Gibbs. Acad. Press, London, 231-261.

Howse, H. D. \& Christmas, J. Y., 1971. Observations on the ultrastructure of lymphocystic virus in the Atlantic croaker, Micropogon undulatus. - Virology 44, 211-214.

Jensen, N. J. \& Larsen, J. L, 1979. The ulcus syndrome in cod (Gadus morhua). I. A pathological and histopathological study. - Nord. VetMed. 31, 221-228.

Jensen, N. J. \& Bloch, B., 1980. Adenovirus-like particles associated with epidermal hyperplasia in cod (Gadus morhua). - Nord. VetMed. 32, 173-175.

Jensen, N. J., Bloch, B. \& Larsen, J. L., 1979. The ulcus syndrome in cod (Gadus morhua). III. A preliminary virological report. - Nord. VetMed. 31, 436-442.

Johnston, M. R. L. \& Davies, A. S., 1973. A Pirhemocyton-like parasite of the blenny, Blennius philis. (Teleostei, Blenniidae) and its relationship to Immanoplasma Newman, 1909. - Int. J. Parasitol. 3, 235-241.

Kimura, T., Yoshimizu, M., Tanaka, M. \& Sannohe, H., 1981a. Studies on a new virus (OMV) from Oncorhynchus masou - I. Characteristics and pathogenicity. - Fish Path. 15, 143-147. 
Kimura, T., Yoshimizu, M. \& Tanaka, M., 1981b. Studies on a new virus (OMV) from Oncorhynchus masou - II. Oncogenic nature. - Fish Path. 15, 149-153.

Kimura, T., Yoshimizu, M. \& Tanaka, M., 1981c. Fish viruses: Tumor induction in Oncorhynchus keta by the herpesvirus. In: Phyletic approaches to cancer. Ed. by C. J. Dawe, J. C. Harshbarger, S. Kondo, T. Sugimura \& S. Takayama. Jap. Scient. Soc. Press, Tokyo, 59-68.

Kimura, T., Yoshimizu, M. \& Tanaka, 1983. Susceptibility of different fry stages of representative salmonid species to Oncorhynchus masou virus (OMV). - Fish Path. 17, 251-258.

Knittel, M. D., 1981. Susceptibility of steelhead trout Salmo gairdneri Richardson to redmouth infection Yersinia ruckeri following exposure to copper. - J. Fish Dis. 4, 33-40.

Koops, H., Mann, H., Pfitzner, I., Schmid, O. J. \& Schubert, G., 1970. The cauliflower disease of eels. In: A symposium on diseases of fishes and shellfishes. Ed. by S. F. Snieszko. Washington, D.C., 291-295. (Spec. Publ. Am. Fish. Soc. 5.)

Krantz, G. E, 1970. Lymphocystis in striped bass, Roccus saxatilis, in Chesapeake Bay, - Chesapeake Sci. 11, 137-139.

Laird, M. \& Bullock, W. L., 1969. Marine fish hematozoa from New Brunswick and New England. J. Fish. Res. Bd Can. 26, 1075-1102.

Lawler, A. R., Ogle, J. T. \& Donnes, C., 1977. Dascyllus spp.: New hosts for lymphocystis and a list of recent hosts. - J. Wildl. Dis, 13, 307-312.

MacMillan, J. R. \& Mulcahy, D., 1979. Artificial transmission to and susceptibility of Puget Sound fish to viral erythrocytic necrosis (VEN). - J. Fish. Res. Bd Can. 36, 1097-1101.

MacMillan, J. R., Mulcahy, D. \& Landolt, M., 1980. Viral erythrocytic necrosis: Some physiological consequences of infection in chum salmon (Oncorhynchus keta). - Can. J. Fish. aquat. Sci. 37, $799-804$

Madeley, C. R., Smail, D. A. \& Egglestone, S. 1., 1978. Observations on the fine structure of lymphocystis virus from European flounders and plaice. - J. gen. Virol. 40, 421-431.

McAllister, P. E., 1979. Fish viruses and viral infections. In: Comprehensive virology. Ed. by H. Fraenkel-Conrat \& R. R. Wagner. Plenum Press, New York, 14, 401-470.

McArn, G. E., McCain, B. \& Wellings, S. R, 1978. Skin lesions and associated virus in Pacific cod (Gadus macrocephalus) in the Bering Sea. - Fedn Proc. Fedn Am. Socs exp. Biol. $37,937$.

McCain, B. B., Gronlund, W. D., Myers, M. S. \& Wellings, S. R., 1979. Tumors and microbial diseases of marine fishes in Alaskan waters. - J. Fish Dis, 2, 111-130.

McCosker, J. E., Lagios, M. D. \& Tucker, T., 1976. Ultrastructure of lymphocystis virus in quillback rockfish (Sebastes maliger) with records of infection in other aquarium fishes. - Trans. Am. Fish. Soc, $105,333-344$.

Murchelano, R. A. \& Bridges, D. W., 1976. Lymphocystis disease in the winter flounder (Pseudopleuronectes americanus). - J. Wildl. Dis. 12, 101-106.

Nagabayashi, T, \& Wolf, K, 1979. Characterization of EV-2, a virus isolated from European eels (Anguilla anguilla) with stomatopapilloma. - J. Virol. 30, 358-364.

Nicholson, B. L. \& Reno, P. W., 1981. Viral erythrocytic necrosis (VEN) in marine fishes. - Fish. Path. $15,129-133$.

Nigrelli, R. F., 1954. Tumors and other atypical cell growths in temperate freshwater fishes of North America. - Trans. Am. Fish. Soc. 83, 262-271.

Paperna, I., Sabnai, I., Colorni, A., 1982. An outbreak of lymphocystis in Sparus aurata L. in the Gulf of Aqaba, Red Sea. - J. Fish Dis. 5, 433-437.

Peters, N. \& Peters, G., 1970. Tumorgenese, ein Energieproblem der Zelle? Untersuchungen an Papillomen des europäischen Aals, Anguilla anguilla. - Arch. FischWiss. 21, 238-247.

Pfitzner, I., 1969. Zur Aetiologie der Blumenkohlkrankheit der Aale. - Arch. FischWiss. 20, 24-49.

Pfitzner, I. \& Schubert, G., 1969. Ein Virus aus dem Blut mit Blumenkohlkrankheit behafteter Aale. - Z. Naturforsch. $24 b, 70$.

Pilcher, K. S. \& Fryer, J. L., 1980. The viral diseases of fish: A review through 1978. Part. 1: Diseases of proven viral etiology. - CRC crit. Rev. Microbiol. 9, 287-363.

Popkova, T. I. \& Schelkunov, I. S., 1978. Isolation of virus from carp afflicted with gill necrosis. (Vedelenie virusa ot karpov, bol'nykh zhabernym nekrozom), - VNIIPRKH Ryb. Khoz. 4, 34-38.

Reno, P. W. \& Nicholson, B. L., 1980. Viral erythrocytic necrosis (VEN) in Atlantic cod (Gadus morhua, L.): In vitro studies. - Can. J. Fish. aquat. Sci. 37, 2276-2281.

Reno, P. W. \& Nicholson, B. L., 1981. Ultrastructure and prevalence of viral erythrocytic necrosis 
(VEN) virus in Atlantic cod (Gadus morhua L.) from the Northern Atlantic Ocean. - J. Fish Dis. 4, $361-370$.

Reno, P. W., Phillippon-Fried, M., Nicholson, B. L. \& Sherburne, S. W., 1978. Ultrastructural studies of piscine erythrocytic necrosis (PEN) in Atlantic herring (Clupea harengus harengus). - J. Fish. Res. Bd Can. 35, 148-154.

Richards, R. H. \& Buchanan, J. S., 1978. Studies on Herpesvirus scophthalmi infection of turbot Scophthalmus maximus: Histopathological observations, - J. Fish Dis. 1, 251-258.

Rijkers, G. T., 1982. Non-lymphoid defensive mechanisms in fish.-Dev. comp. Immunol, 6, 1-12.

Roales, R. R. \& Perlmutter, A., 1977. The effects of sublethal doses of methylmercury and copper, applied singly and jointly, on the immune response of the blue gourami (Trichogaster trichopte* rus) to viral and bacterial antigens. - Archs environ. Contam. Toxicol, 5, 325-331.

Roberts, R. J. \& Bullock, A. M., 1979. Papillomatosis in marine cultured rainbow trout Salmo gairdneri Richardson. - J. Fish Dis. 2, 75-77.

Robin, J. \& Berthiaume, L., 1981. Purification of lymphocystis disease virus (LDV) grown in tissue culture. Evidences for the presence of two types of viral particles. - Rev. Can. Biol. 40, 323-329.

Rohovec, J. S. \& Amandi, A., 1981. Incidence of viral erythrocytic necrosis among hatchery reared salmonids of Oregon. $-\mathrm{J}$. Fish Path. 15, 135-141.

Russell, P. H., 1974. Lymphocystis in wild plaice (Pleuronectes platessa) and flounder (Platichthys flesus) in British coastal waters - A histological and serological study. - J. Fish Biol. 6, 771-778.

Sano, T., 1976. Viral diseases of cultured fishes in Japan. - Fish. Path. 10, 221-226.

Sarot, D. A. \& Perlmutter, A., 1976. The toxicity of zinc to the immune response of the zebrafish (Brachydanio rerio), injected with viral and bacterial antigens. - Trans. Am. Fish. Soc. 105, $456-459$.

Schmid, O. J., 1969. Beitrag zur Histologie und Aetiologie der Blumenkohlkrankheit der Aale. Arch. FischWiss, 20, 16-22.

Schubert, G. H, 1966. The infective agent of carp pox. -- Bull. Off. int. Epizoot. 65, 1011-1022.

Scott, A. L. \& Klesius, P. H., 1981. Chemiluminescence: A novel analysis of phagocytosis in fish. Devs biol. Stand. 49, 243-256.

Sherburne, S. W., 1977. Occurrence of piscine erythrocytic necrosis (PEN) in the blood of the anadromous alewife, Alosa pseudoharengus, from Maine coastal streams. - J. Fish. Res. Bd Can. $34,281-286$.

Sindermann, C. J., 1970. Principal diseases of marine fish and shellfish. Acad. Press, New York, $369 \mathrm{pp}$.

Sindermann, C. J., 1979. Pollution-associated diseases and abnormalities of fish and shellfish Review. - Fish. Bull. U. S. 76, 717-749.

Smail, D. A. \& Egglestone, S. I., 1980. Virus infections of marine fish erythrocytes: prevalence of piscine erythrocytic necrosis in cod Gadus morhua L. and blenny Blennius pholis L. in coastal and offshore waters of the United Kingdom. - J. Fish Dis. 3, 41-46.

Snieszko, S. F., 1974. The effects of environmental stress on outbreaks of infectious diseases of fish. - Fish Biol. 6, 197-208.

Sonstegard, R. A. \& Sonstegard, K. S., 1978. Herpesvirus - associated epidermal hyperplasia in fish (carp). - Scient. Publ. int. Ag. Res. Cancer 24,863-868.

Stave, J., Roberson, B. S. \& Hetrick, F. M., 1983. Chemiluminescence of phagocytic cells isolated from the pronephros of striped bass. - Dev, comp. Immunol. 7, 269-276.

Stehbens, W. E. \& Johnston, M. R. L., 1966. The viral nature of Pirhemocyton tarentolae. - J. Ultrastruct. Res. 15, 543-554.

Stephens, E. B., Newman, M. W., Zachary, A. L. \& Hetrick, F. M., 1980. A viral aetiology for the annual spring epizootics of Atlantic menhaden in Chesapeake Bay. - J. Fish Dis. 3, $387-398$.

Stickney, R. R. \& White, D. B., 1974. Lymphocystis in tank-cultured flounder. - Aquaculture 4 , $307-308$.

Sugatt, R. H., 1980. Effects of sodium dichromate exposure on the immune responses of juvenile coho salmon, Oncorhynchus kisutch, against Vibrio anguillarum. - Archs environ. Contam. Toxicol. $9,207-216$.

Vitinsh, M. \& Baranova, T., 1976. Lymphocystis disease of Baltic flounder (Platichthys flesus). C.M./ICES P6. 
Walker, D. P. \& Hill, B. J., 1980. Studies on the culture, assay of infectivity, and some in vitro properties of lymphocystis virus. - J. gen. Virol. 51, 383-395.

Walker, R, 1962. Fine structure of lymphocystis virus of fish. - Virology 18, 503-505.

Walker, R, 1965. Viral DNA and cytoplasmic RNA in lymphocystis cells of fish. - Ann. N. Y. Acad. Sci. $126,386-395$.

Walker, R, 1971. PEN, a viral lesion of fish erythrocytes. - Am. Zool. 11, 707.

Walker, R. \& Sherburne, S. W., 1977. Piscine erythrocytic necrosis in Atlantic cod, Gadus morhua, and other fish: Ultrastructure and distribution. - J. Fish. Res. Bd Can. 34, 1188-1195.

Walker, R. \& Weissenberg, R., 1965. Conformity of light and electron microscopic studies on virus particle distribution in lymphocystic tumour cells of fish. - Ann. N. Y. Acad. Sci. 126, 375-385.

Walker, R. \& Wolf, K., 1962. Virus array in lymphocystis cells of sunfish. - Am. Zool. 2, 566.

Wedemeyer, G. A., Meyer, F. P. \& Smith, L., 1976. Environmental stress and fish diseases. In: Diseases of fish. Ed. by S. F. Snieszko \& H. R. Axelrod. T. F. H. Publications, Hong Kong, 5, 73-88.

Weissenberg, R., 1945. Studies on virus diseases of fish. IV. Lymphocystis disease in centrarchidae. - Zoologica N. Y. 30, 169-176.

Weissenberg, $R$, 1951. Positive result of a filtration experiment supporting the view that the agent of the lymphocystis disease of fish is a true virus. - Anat. Rec. 111, 166-171.

Weissenberg. R., 1965. Fifty years of research on the lymphocystis virus disease of fishes (1914-1964). - Ann. N. Y. Acad. Sci. 126, 362.

Wiren, B., 1971. Wart disease in Atlantic salmon (Salmo salar) - Histological studies of epidermal papilloma in reared salmon. - Rep. Swed. Salmon Res. Inst., Alvkarleby 7, 1-9.

Wolf, K., 1962. Experimental propagation of lymphocystis disease of fishes. - Virology 18, $249-256$.

Wolf, K., 1966. The fish viruses. - Adv. Virus Res. 12, 35-101.

Wolf, K., 1968. Lymphocystis disease of fish. Fish Dis. Leafl. - Fish Wildl. Serv, U. S. 13, 1-4.

Wolf, K., 1976. Fish viral diseases in North America, 1971-75, and recent research of the Eastern Fish Disease Laboratory USA. - Fish Path. 10, 135-154.

Wolf, K., 1979. Comparative pathogenesis and virulence of poikilotherm vertebrate Herpesviruses. In: Munich Symposium on Microbiology of viral pathogenesis and virulence. Ed. by $P$. A. Bachmann. WHO Collaborating Centre for Collection and Evaluation of Data on Comparative Virology, Munich, 183-200.

Wolf, K., 1982. Newly discovered viruses and viral diseases of fishes, 1977-1981. In: Microbial diseases of fish. Ed. by R. J. Roberts. Acad. Press, London, 59-90.

Wolf, K. \& Carlson, C. P., 1965. Multiplication of lymphocystis virus in the bluegill (Lepomis macrochirus), - Ann. N. Y. Acad. Sci. 126, 414-419.

Wolf, K. \& Quimby, M. C., 1970. Virology of eel stomatopapilloma. In: Progress in sport fishery research 1969. Resource Publ. Fish Wildl. Serv., U. S. 106, 94-95.

Wolf, K. \& Smith, C. E., 1981. Herpesvirus salmonis: pathological changes in parenterally-infected rainbow trout, Salmo gairdneri Richardson, fry. - J. Fish Dis. 4, 445-457.

Wolf, K., Gravell, M. \& Malsberger, R. G., 1966. Lymphocystis virus: isolation and propagation in centrarchid fish cell lines. - Science, N. Y. 151, 1004-1005.

Wolf, K., Nagabayashi, T. \& Quimby, M. C., 1975a. Herpesvirus salmonis: tests of species specificity, suggestions for isolation, geographic distribution ${ }_{z}$ and control measures. - Fish HIth News 4,6 .

Wolf, K., Herman, R. L., Darlington, R. W. \& Taylor, W. G., 1975b. Salmonid virus: effects of Herpesvirus salmonis in rainbow trout fry. - Fish HIth News 4, 8.

Wolf, K., Darlington, R. W., Taylor, W. G., Quimby, M. C. \& Nagabayashi, T., 1978. Herpesvirus salmonis: characterization of a new pathogen of rainbow trout. - J. Virol. 27, 659-666.

Zwillenberg, L. O. \& Wolf, K., 1968. Ultrastructure of lymphocystis virus. - J. Virol. 2, 393-399. 